\title{
Enormous Earthquake in Japan: Coping with Stress Using Purpose-in-Life/Ikigai
}

\author{
Riichiro Ishida \\ Faculty of Medicine, Niigata University, Niigata, Japan. \\ Email: ishida-riichiro@hb.tp1.jp \\ Received July 21 ${ }^{\text {st }}$ 2011; revised August 24 ${ }^{\text {th }}$, 2011; accepted September $21^{\text {st }}, 2011$.
}

\begin{abstract}
Every person has a will to achieve meaning and purpose in life (PIL)/ikigai. According to previous studies, PIL/ikigai provides people with the ability to integrate stressful psychological events from the past, present, and future with less conflict or confusion. This ability results in decreased anxiety and lower sympathetic nervous system activity during psychological and physical stressful situations. PIL/ikigai develops by positive experiences in one's life such as experiencing sympathetic listening by others and being affected by persons and/or events. Overall, evidence shows that PIL/ikigai is an effective technique for coping with stress and helped many people cope with the enormous earthquake that occurred in Japan in March 2011.
\end{abstract}

Keywords: The East Japan Enormous Earthquake, Stress, Purpose in Life, Ikigai

\section{Introduction}

Many people are aware of the enormous earthquake that took place in eastern Japan on March 11, 2011. The earthquake had a magnitude of 9 (7 on the Japanese scale) and triggered a tsunami with a height of more than 10 meters. These events, including many large aftershocks, destroyed cities over a vast area. Furthermore, the earthquake and subsequent tsunami resulted in a serious accident at a nuclear power plant (Tokyo Electric Co., Ltd., in Fukushima Prefecture) that led to a radiation leak from the damaged plant [The Niigata Nippo, March 13, 2011]. This radiation leak led to many misconceptions and fears among Japanese citizens. As a result of these events, a large number of people had to leave their homes and live in gymnasiums or fabricated houses. Many people, including children, continue to cope with the consequences of these events. The recovery efforts and rescue and relief activities have been ongoing, and many people involved in these processes are showing signs of mental and physical fatigue. The clean up from this disaster is also expected to continue for a long period and contribute to increased stress. Effective techniques for coping with stress should be shared with victims of this disaster. Based on previous studies, the author wishes to propose to psychologists that achieving meaning or purpose-in-life (PIL)/ ikigai is an effective technique for coping with stress.

\section{Stress}

Anxiety is associated with an unknown future in the face of various conflicts and types of confusion [Atkinson, Atkinson, Smith, Ben, \& Nolen-Hoesksema, 1996; Smith, Nolen-Hoeksema, Fredrickson, \& Loftus, 2003]. Any stress causes anxiety and can lead to imbalances in the autonomic nervous system [Atkinson et al., 1996; Smith et al., 2003]. If the stressful event continues and/or the person cannot effectively cope with the stress, he/she may experience mental and/or physical diseases such as depression or coronary heart disease [Atkinson et al., 1996; Smith et al., 2003]. Thus, stress affects both the mind and the body.

\section{Coping with Stress Using PIL/Ikigai}

Many philosophical, literal, religious, psychological, and medical techniques for coping with stress have been proposed [e.g., Arai, 2007; Fahrenbach, 1907; Ginger, 1995; Irie, 1982; Ishida \& Okada, 2001; Kida, 2006, Atkinson et al., 1996; Pascal,1897; Smith et al., 2003]. Recently, we found evidence that "PIL and "ikigai," two social attitudes, have been identified as effective techniques for coping with various kind of stress [Ishida, 2008a; Ishida, 2008b; Ishida \& Okada, 2006; Ishida \& Okada, 2011a; Ishida \& Okada, 2011b; Ishida \& Okada, 2011c; Ishida, Okada, \& Bando, 2004a; Ishida, Okada, \& Bando, 2004 b]. PIL is based on the existential philosophy that appeared in Europe and has been around for more than 150 years [Kida, 2006]. Its basic premise is "Everything changes. You only get one chance at life. Every person should achieve meaning in one's life [Ofman, 1980]". The idea that "everything changes" has existed for centuries, appearing in Japanese classical literature from the 12th century [Takagi, Ozawa, Atsumi, \& Kindaichi, 1959]. "Ikigai” means "worth living” or "meaningfulness of life," and appeared in the Japanese classical literature in the 14th century [Goto \& Kamada, 1960]. PIL and ikigai are commonly based on the intrinsic and natural motivation that "Every person has a will to achieve meaning in one's life [Crumbaugh \& Maholic, 1972; Frankl, 1972; Kamiya, 2004; Kuroda, 1966]," and proposes the importance of "now" "here" and "goal orientation in the future". Those without PIL/ikigai commonly feel empty of mind, that is, live in an existential vacuum [Crumbaugh \& Maholic, 1972; Frankl, 1972; Kamiya, 2004; Kuroda, 1966]. In addition, those without PIL/ikigai also have a strong need for approval from others [Ishida \& Okada, 2011a]. In contrast, those with PIL/ikigai commonly perform tasks for their own satisfaction and pleasure rather than to gain approval from others [Allen, 2000; Bundra, 1997; Ueda, 1993]. However, this does not mean they think of only themselves and ignore others' happiness but rather indicates that they transfer their interest from themselves to other people and events. [Kamiya, 2004; Kuroda, 1966; Kuroda, 1969].

According to our studies, PIL/ikigai provides people with the ability to integrate stressful psychological events in the past, 
present, and future with less conflict or confusion [Ishida, 2008a; Ishida, 2008b; Ishida \& Okada, 2006; Ishida \& Okada, 2011a; Ishida \& Okada, 2011b; Ishida \& Okada, 2011c; Ishida, Okada, \& Bando, 2004a; Ishida, Okada, \& Bando, 2004b]. This ability results in decreased anxiety and lower sympathetic nervous system activity during psychological and physical stressful situations such performing a time-limited task that will be evaluated by others, or meeting a person for the first time [Ishida, 2008a; Ishida, 2008b; Ishida \& Okada, 2006; Ishida \& Okada, 2011a; Ishida \& Okada, 2011b; Ishida \& Okada, 2011c; Ishida, Okada, \& Bando, 2004a; Ishida, Okada, \& Bando, 2004 b]. PIL/ikigai decreases psychiatric/somatic symptoms under stressful situations [Ishida \& Okada, 2006; Ishida]. This, in turn, influences the immune function and decreases the mortality risk [Abo \& Kawamura, 2002; Hui \& Fung, 2009; Koizumi, Kaneko, \& Motohashi, 2008; Krause, 2009; Kremer \& Ironson, 2009; Murata, Kondo, Tamakoshi, Yatsuya, \& Toyoshima, 2006; Nakanishi, Fukuda, Takatorige, \& Tatara, 2005; Pinquart, Silbereisen, \& Fröhlich, 2009; Seki, 2001; Sone et al., 2008; Tanno \& Sakata, 2007]. These studies suggest the value of PIL/ ikigai.

\section{How PIL/Ikigai Contributes to Life Even in a Stressful Environment}

Newspapers in Japan often report victims of the earthquake disaster from viewpoint of PIL/ikigai. Several examples follow:

Patient helper (female, 62 years old): This woman has worked as a helper for patients in the damaged prefecture and lives in a gymnasium with other families. She regrets that she could not send old aged patients to their home safely on the day of the earthquake. She has experience as an aerobic exercise instructor for dementia patients at an institution. She started to teach aerobic exercise with music for others in the gymnasium and experiences great satisfaction at seeing others' faces fill with pleasure. Her students say: "We have most interesting time during aerobic exercise with others.” (The Yomiuri Shimbun, July 8, 2011).

Junior high school student group (males and females, 12 - 14 years old): People living in fabricated houses get to appreciate Japanese traditional dance in their area. Junior high school students who engage in cleaning gymnasiums and fabricated houses as volunteers decided to engage people with dance. This allowed them to exercise and exhibit their skills. An old woman, one of people who was watching, remembered her granddaughter who died during the earthquake and was moved to tears while watching. The students decided to do dance exhibitions from now on to give vitality and pleasure to people establishing lives in a new area. (The Yomiuri Shimbun, July 8, 2011).

Retired person (male, 68 years old): He lived in a gymnasium and now lives in a fabricated house after losing his wife and dog to the tsunami. Along with volunteers of a nonprofit organization, he planted morning glories on the outside of the fabricated house. He says "I experience great pleasure caring for the morning glories and touching the earth.” (The Mainichi Shimbun, May 31, 2011).

Oyster farmer (male, 43 years old): He has engaged in planting oysters for 25 years. He lives in his half-broken house and lost his fishing boat to the tsunami. However he cleans the beach every day and is attempting to start planting oysters for people who like eating them. (The Mainichi Shimbun, May 31, 2011).

Housewife (66 years old): She took out an address book when she and her husband escaped from their house on the day of the earthquake. She lives in a fabricated house with three grandsons and a granddaughter who lost their mother. She decided to keep a diary in the address book. She firmly believes that describing the events relating to the earthquake in the diary will help people in the future. (The Asahi Shimbun, July 6, 2011).

School teacher (male, 26 years old): He worked at a junior high school as a supporter for retarded students and was a basketball coach in the school club. He escaped to the third floor of the school with his students on that day of tsunami and now lives in a school with other people. He takes great pleasure being a volunteer basketball coach for junior high school students now. (The Asahi Shimbun, May 31, 2011).

Paralympics athlete (male, 62 years old): He was a medalist in the discus throw in the Paralympics. He could not move the lower half of his body after an accident that occurred when he was 40 years old and worked on a ship as a fishermen. When he was 49 years old, his friend taught him the discus throw. His house was not destroyed by tsunami, but a lack of oil kept him from training at the rehabilitation institute, and this broken exercise routine meant he could not perform in the Paralympics. In spite of these events, he started training at a nearby track field with his wife's support; she measures his throwing distance. (The Yomiuri Shimbun, July 3, 2011).

Restaurant manager (male, 40 years old): He lost two restaurants and a bar to the tsunami. In spite of these events, he started a business again using used a ramen shop with an only area of $30 \mathrm{~m}^{2}$ and opened a sailing car that sells grilled meat and omelets. His goal is to ensure that the people in the area eat, drink, and smile. (The Mainichi Shimbun, July 4, 2011).

\section{Proposals for Development of PIL/Ikigai}

Many events correlate with the development of PIL/ikigai, including the recent disaster in Japan. These events often provide people, including victims, with a chance to consider important questions such as "What is the relation between nature and human beings?", "What was the meaning of my former life?", "What was the meaning of another person's life?", "What is a real happiness?", and "How should I live from now on?”. These questions may help people establish PIL/ikigai.

Several techniques can help with the development of PIL/ ikigai. One involves finding people who will "listen with sympathy”. People tend to feel worried, conflicted, and confused when attempting to solve problems on their own. This process can lead to the development of anxiety. However, sympathetic listening by others can help a person integrate stressful psychological events, which can decrease anxiety. Sympathetic listeners can include parents, friends, teachers, neighbors, and psychological counselors. It should be noted, however, that the main job of the listener is to provide a sympathetic ear and not to try to solve the problem for the person.

Another technique to help with the development of PIL/ikigai is "affecting persons and/or events". When person is affected by people and events, his/her anxiety may decrease. For example, many entertainers, comedians, athletes, novelists, and others visited the disaster area in Japan and have taken part in various activities with victims, such as singing songs, talking, performing magic shows, playing baseball, reading picture books, and cooking. These events can help people relax and feel less anxiety. Similarly, seeing members of Self-DefenseForces, police officers, fire fighters, other groups, and individuals from not only the damaged prefectures but also from other 
areas, as well as people from other countries, take part in recovery efforts and rescue and relief activities, also impacts people. In many cases, seeing people "give back" to others can inspire them to give of themselves, which is an important factor in the establishment of PIL/ikigai.

\section{Conclusions}

“The East Japan Enormous Earthquake" traumatized many people, both physically and psychologically, and receiving warm-hearted support from friends and strangers has helped many people deal with this disaster. The earthquake and the warmhearted support will provide people with a chance to consider the meaning of one's life and contribute to developing PIL/ ikigai as an effective technique for coping with stress.

\section{Note}

This manuscript was completed four months after the earthquake (July 10, 2011).

\section{References}

Abo, T., \& Kawamura, T. (2002). Immunomodulation by the autonomic nervous system: Therapeutic approach for cancer, collagen disease, and inflammatory bowel diseases. Therapeutic Apheresis, 6, 348-357. doi:10.1046/j.1526-0968.2002.00452.x

Allen, B. P. (2000). Personality theories. Boston: Allyn and Bacon.

Arai, M. (2007). Ju gyu zu. Tokyo: Shinki-Sha. (in Japanese)

Atkinson, R. L., Atkinson, R. C., Smith, E. E., Ben, D. J., \& NolenHosk-sema, S. (1996). Hilgard's introduction to psychology. Fort Worth: Harcourt Brace College Publishers.

Bundra, A. (1997). Social learning theory. Upper Saddle River: Prentice Hall.

Crumbaugh, J. C., \& Maholic, L. T. (1972). An experimental study in existentialism: The psychometric approach to Frankl's concept of noogenic neurosis. Journal of Clinical Psychology, 20, 200-207. doi:10.1002/1097-4679(196404)20:2<200::AID-JCLP2270200203> 3.0.CO;2-U

Fahrenbach, H. (1907). Existenzphilosophie und ethik. Frakfurt: Verlag Vittoro Klostermann. (in German)

Frankl, V. E. (1972). The meaning of meaninglessness: A challenge to psychotherapy. American Journal of Psychoanalysis, 32, 85-89.

Ginger, S. (1995). La gestalt-l'Art du contact. Alleur (Belgique): Marabout. (in French) doi:10.1007/BF01872487

Goto, T., \& Kamada, K. (1960). Taiheiki. Tokyo: Iwanami-Shoten. (in Japanese)

Hui, V. K., \& Fung, H. H. (2009). Mortality anxiety as a function of intrinsic religiosity and perceived purpose in life. Death Studies, 33, 30-50. doi:10.1080/07481180802494099

Irie, Y. (1982). Ryokan shisyu. Tokyo: Kodan-Sha. (in Japanese)

Ishida, R. (2008a). Correlation between purpose in life (ikigai) and state anxiety in schizoid temperament with consideration of early life, youth, and adulthood experiences. Acta Medica et Biologica, 56, 2732.

Ishida, R. (2008b). Correlation between social desirability and autonomic nervous function under goal-oriented stress (mental arithmetic) with consideration of parental attitudes. The Autonomic Nervous System, 45, 242-249. (in Japanese)

Ishida, R., \& Okada, M. (2001). Analysis of correlation between physical training and autonomic function by using multivariate analysis: Establishing an indicator of health. Rinsyo Byori, 49, 1162-1165. (in Japanese)

Ishida, R., \& kada, M. (2006). Effects of a firm purpose in life on anxiety and sympathetic nervous activity caused by emotional stress: Assessment by psycho-physiological method. Stress and Health, 22, 275-281. doi:10.1002/smi.1095

Ishida, R., \& Okada, M. (2011a). Factors influencing the development of "Purpose in Life" and its relationship to coping with mental stress.
Psychology, 2, 29-34. doi:10.4236/psych.2011.21005

Ishida, R., \& Okada, M. (2011b). Emotion and the autonomic nervous activity against psychological stress are affected by firmness of purpose in life. Health, 3, 507-511. doi:10.4236/health.2011.38084

Ishida, R., \& Okada, M. (2011c). Association of trait anxiety and social desirability with white blood cell counts. The Open Psychiatry Journal, 5, 1-4.

Ishida, R., Okada, M., \& Bando, T. (2004a). Relation between level of purpose-in-life and the autonomic nervous function under a mental stress. Niigata Medical Journal, 118, 333-339. (in Japanese)

Ishida, R., Okada, M., \& Bando, T. (2004b). Evaluations of the adaptation to stressors by using psycho-physiological methods: Contribution to the youth education. The Autonomic Nervous System, 41, 419422. (in Japanese)

Kamiya, M. (2004). Ikigai ni tsuite. Tokyo: Misuzu-Shobo. (in Japanese)

Kida, G. (2006). Gendai shiso. Tokyo: Shin-Shokan. (in Japanese)

Koizumi, M., Ito, H., Kaneko, Y., \& Motohashi, Y. (2008). Effect of having a sense of purpose in life on the risk of death from cardiovascular diseases. Journal of Epidemiology, 8, 191-196. doi:10.2188/jea.JE2007388

Krause, N. (2009). Meaning in life and mortality. The Journals of Gerontology, Series B, Psychological Sciences and Social Sciences, 64, 517-527. doi:10.1093/geronb/gbp047

Kremer, H., \& Ironson, G. (2009). Everything changed: Spiritual transformation in people with HIV. International Journal of Psychiatry in Medicine, 39, 243-262. doi:10.2190/PM.39.3.c

Kuroda, M. (1966). Ningen no riso ni tsuite. Niigata: Niigata Prefecture Mental Hygiene Society. (in Japanese)

Kuroda, M. (1969). Kokoro no eisei. Tokyo: Kyodo-Shuppan. (in Japanese)

McColl, M. A., Bickenbach, J., Johnston, J., Nishihama, S., Schumaker, M., Smith, K., Smith, M., \& Yealland, B. (2000). Changes in spiritual beliefs after traumatic disability. Archives of Physical Medicine and Rehabilitation, 81, 817-823.

Murata, C., Kondo, T., Tamakoshi, K., Yatsuya, H., \& Toyoshima, H. (2006). Determinants of self-rated health: Could health status explain the association between self-rated health and mortality? Archives Gerontology Geriatrics, 43, 369-380. doi:10.1016/j.archger.2006.01.002

Nakanishi, N., Fukuda, H., Takatorige, T., \& Tatara, K. (2005). Relationship between self-assessed masticatory disability and 9-year mortality in a cohort of community-residing elderly people. Journal of the American Geriatrics Society, 53, 54-58. doi:10.1111/j.1532-5415.2005.53010.x

Ofman, W. V. (1980). Existential psychotherapy. In H. I. Kaplan, A. M. Freedman and B. J. Sadock (Eds.), Comprehensive textbook of psychiatry/III (pp. 837-847). Baltimore: Williams \& Wilkins Company.

Pascal, B. (1897). Pensées. Paris: Hachette. (in French)

Pinquart, M., Silbereisen, R. K., \& Fröhlich, C. (2009). Life goals and purpose in life in cancer patients. Supportive Care in Cancer, 17, 253-259. doi:10.1007/s00520-008-0450-0

Seki, N. (2001). Relationships between walking hours, sleeping hours, meaningfulness of life (ikigai) and mortality in the elderly: Prospective cohort study. Nippon Eiseigaku Zassi, 56, 535-540. (in Japanese) doi:10.1265/jjh.56.535

Smith, E. E., Nolen-Hoeksema, S., Fredrickson, B. K., \& Loftus, G. R. (2003). Atkinson \& Hilgard's introduction to psychology, Thomson.

Sone, T., Nakaya, N., Ohmori, K., Shimazu, T., Higashiguchi, M., Kikuchi, N., Kuriyama, S., \& Tsuji, I. (2008). Sense of life worth living (ikigai) and mortality in Japan: Ohsaki study. Psychosomatic Medicine, 70, 709-715. doi:10.1097/PSY.0b013e31817e7e64

Takagi, I., Ozawa, M., Atsumi, K., \& Kindaichi, H. (1959). Heike monogatari. Tokyo: Iwanami-Shoten. (in Japanese)

Tanno, K., \& Sakata, K. (2007). Psychological factors and mortality in the Japan Collaborative Cohort Study for Evaluation of Cancer (JACC). Asian Pacific Journal of Cancer Prevention, 8, 113-122.

The Asahi Shimbun, May 31, 2011. (in Japanese)

The Asahi Shimbun, July 6, 2011. (in Japanese)

The Mainichi Shimbun, May 31, 2011. (in Japanese)

The Mainichi Shimbun, July 4, 2011. (in Japanese)

The Niigata Nippo, March 13, 2011. (in Japanese)

The Yomiuri Shimbun, July 3, 2011. (in Japanese) 
The Yomiuri Shimbun, July 8, 2011. (in Japanese)

Shoten. (in Japanese)

Ueda, K. (1993). Seishinteki ni kenko na ningen. Tokyo: Kawashima- 